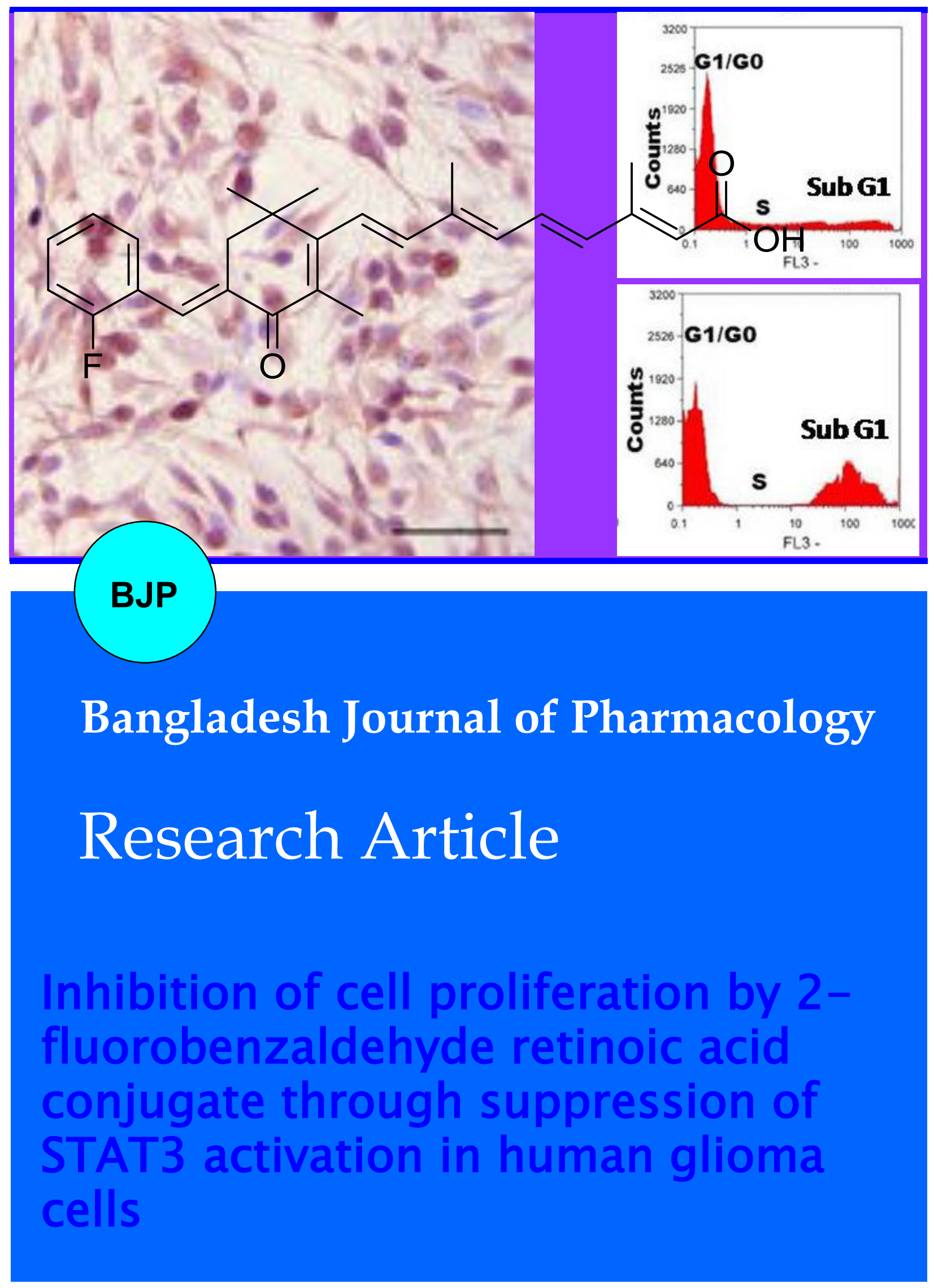




\title{
Inhibition of cell proliferation by 2 -fluorobenzaldehyde retinoic acid conjugate through suppression of STAT3 activation in human glioma cells
}

\author{
Ji-Heng Hao',2, Dian-Feng Hu², Li-Mei Mao³, Shi-Gang Zhang², Ji-Yue Wang² and Gang Li' \\ ${ }^{1}$ Department of Neurosurgery, Qilu Hospital of Shandong University, Jinan City 250012, Shandong Province, China; \\ ${ }^{2}$ Department of Neurosurgery, Liaocheng People's Hospital and Liaocheng Clinical School of Taishan Medical \\ University, Liaocheng City 252000, Shandong Province, China; 'Department of Health, Liaocheng People's Hospital \\ and Liaocheng Clinical School of Taishan Medical University, Liaocheng City 252000, Shandong Province, China.
}

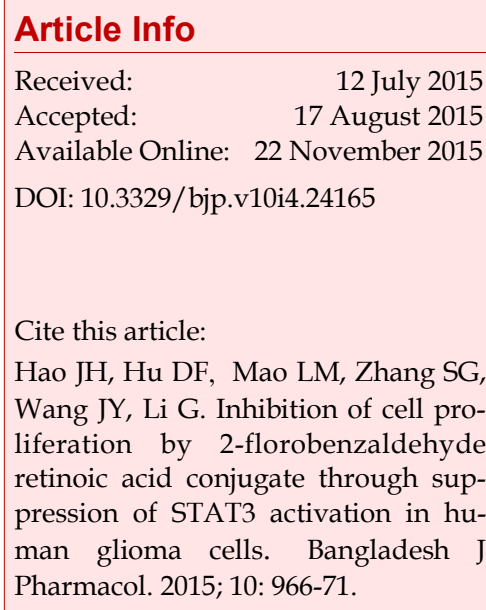

\begin{abstract}
The present study was performed to investigate the effect of 2-fluorobenzaldehyde retinoic acid conjugate on activation of STAT3 pathway in human glioma cells. The results revealed that the compound exhibited inhibitory effect on the activation of STAT3 induced constitutively and by interleukin-6. The inhibitory effect on STAT3 activation was found to be concentration- and time-dependent. In U373 glioma cells, 2-fluorobenz-aldehyde retinoic acid conjugate treatment caused a significant enhancement in the expression of proapoptotic proteins like Bax and Bak. Its treatment inhibited the expression of genes including, cyclin D1, Bcl-2, Bcl-xL, survivin, Mcl-1, and vascular endothelial growth factor (VEGF) in U373 glioma cells. Furthermore, the conjugate inhibited proliferation, induced apoptosis and caused accumulation of cells in G1-G0 phase of cell cycle. Thus, 2-fluorobenzaldehyde retinoic acid conjugate acts as a potent inhibitor of STAT3 activation that can be promising importance for the prevention and treatment of gliomas.
\end{abstract}

\section{Introduction}

Glioma, one of the frequently detected primary brain tumors in adults has around 3 months of median survival in patients availing no treatment $(\mathrm{Ng}$ et al., 2007). The rapid rate of proliferation, invasion and metastasis in combination with poor prognosis demand for the novel treatment strategies (Lin et al., 2008; PaezRibes et al., 2009). Therefore, researchers are investigating the various signaling pathways in order to develop therapeutic agents to treat the glioma (Gan et al., 2009; Jang et al., 2008).

Survival and proliferation of tumor cells are regulated by the members of signal transducer and activator of transcription (STAT) protein family, including STAT3 (di Tomaso et al., 2009). In various types of carcinoma cells, STAT3 is found to be present in higher level (Darnell, 2002; Buettner et al., 2002). The Janus activated kinase, JAK2 also plays an important role in the activation of STAT3 (Ihle, 1996; Ren and Schaefer, 2002). Phosphorylation of STAT3 induces the expression of genes involved in cell proliferation, survival and angiogenesis (Gao and Bromberg, 2006).

Retinoic acid exhibits inhibitory effect on the colon cancer (Zheng et al., 1999), prostate cancer (Liang et al., 1999) and lung cancer (Weber et al., 1999). Retinoic acid has also been shown to be of vital importance in the treatment of recurrent malignant cerebral gliomas (Yung et al., 1994). Some of the promising effects of retinoic acid treatment in human malignant gliomas anti-proliferation, anti-migration and anti-invasive activity (Bouterfa et al., 2000; Rotan, 1991). The present study 
was aimed to investigate the effect of 2-fluorobenzaldehyde retinoic acid conjugate (Figure 1) on the proliferation, STAT3 activation, and expression of pro-apoptotic, anti-apoptotic and angiogenesis genes in glioma cells.

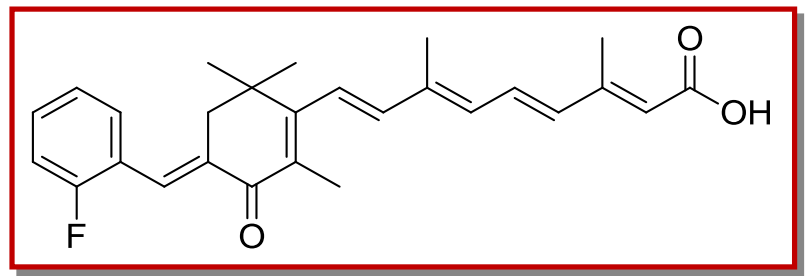

Figure 1: Structure of 2-florobenzaldehyde retinoic acid chalcone

\section{Materials and Methods}

\section{Reagents}

Retinoic acid, bovine serum albumin and 3-(4,5dimethylthiazol-2-yl)-2,5-diphenyltetrazolium bromide were obtained from Sigma-Aldrich (USA). 2florobenzaldehyde retinoic acid conjugate (RAC) stock solution $(20 \mathrm{mmol} / \mathrm{L})$ was prepared in dimethyl sulfoxide and stored at $0^{\circ} \mathrm{C}$.

\section{Synthesis of retinoic acid chalcone}

Retinoic acid was oxidized with Dess Martin periodinane (DMP) in dichloromethane at room temperature. The oxidized product was treated with $\mathrm{KOH}(1 \mathrm{eq})$ and 2florobenzaldehyde (1 eq) at $70^{\circ} \mathrm{C}$ to afford the desired product, 2-florobenzaldehyde retinoic acid conjugate (Scheme 1).

\section{Cell culture and cell viability assay}

Human glioma cell line, U373 was obtained from American Type Culture Collection (ATCC, USA). The cells were cultured in Dulbecco's modified Eagle's medium (USA) containing 10\% fetal bovine serum and antibiotics at $37^{\circ} \mathrm{C}$ in humidified atmosphere of $5 \% \mathrm{CO}_{2}$.

\section{Cell proliferation assay}

U373 glioma cells at a density of $3 \times 10^{5}$ cells per well were distributed onto 96-well plates and cultured overnight. The cells were treated with various concentrations of 2- fluorobenzaldehyde retinoic acid conjugate for 24 hours. The effect on cell proliferation was determined using BrdU assay kit (Roche Diagnostics, Germany). Incubation with the reagent was performed according to the manufacturer's instructions. Absorbance for each well of the plate was measured at $455 \mathrm{~nm}$ using spectrometer.

\section{Western blotting}

U373 glioma cells were incubated with various concentration of 2-fluorobenzaldehyde retinoic acid conjugate or DMSO as control for 48 hours. The cells were washed twice with ice-cold PBS followed by lysis in 1x RIPA lysis buffer for $20 \mathrm{~min}$. For the determination of protein concentration in the cell lysate protein assay (Bio-Rad, Hercules, CA, USA) was used. The lysates were resolved on SDSPAGE and then transferred to polyvinylidene fluoride (PVDF) membranes (Millipore, USA). Incubation of the membranes was performed overnight with primary antibodies polyclonal rabbit anti-human $\beta$-actin, antibodies against STAT, survivin, Bcl-2, Bcl-xL, cyclin D1, VEGF, and caspase-3 antibodies (Danvers, USA). The membranes after washing with PBS were incubated with anti-mouse or anti-rabbit horseradish peroxidase-conjugated IgG (Promega Corporation). The Western Lightning ${ }^{\circledR}$ Plus enhanced chemiluminescence (ECL) substrate (PerkinElmer) and autoradiography was used for visualization of protein expression. The densitometric analysis of X-ray films was performed with Alpha Imager System (ProteinSimple, Santa Clara, CA, USA) using Alpha View software.

\section{Determination of apoptosis in $U 373$ cells}

Analysis of apoptosis in U373 glioma cells was performed by using annexin V-FITC apoptosis detection kit (MBL) and propidium iodide stain. U373 cells seeded on tissue culture slides were allowed to attach for 24 hours followed by treatment with 2-fluorobenzaldehyde retinoic acid conjugate for 48 hours. The cells were treated with $1 x$ binding buffer $(200 \mu \mathrm{L})$, annexin V-FITC $(5 \mu \mathrm{L})$ and propidium iodide $(5 \mu \mathrm{L})$. Following incubation under dark conditions for $5 \mathrm{~min}$ at $37^{\circ} \mathrm{C}$, fluorescent microscopy (BD FacsCalibur) was used to analyze the number of viable and apoptotic cells.

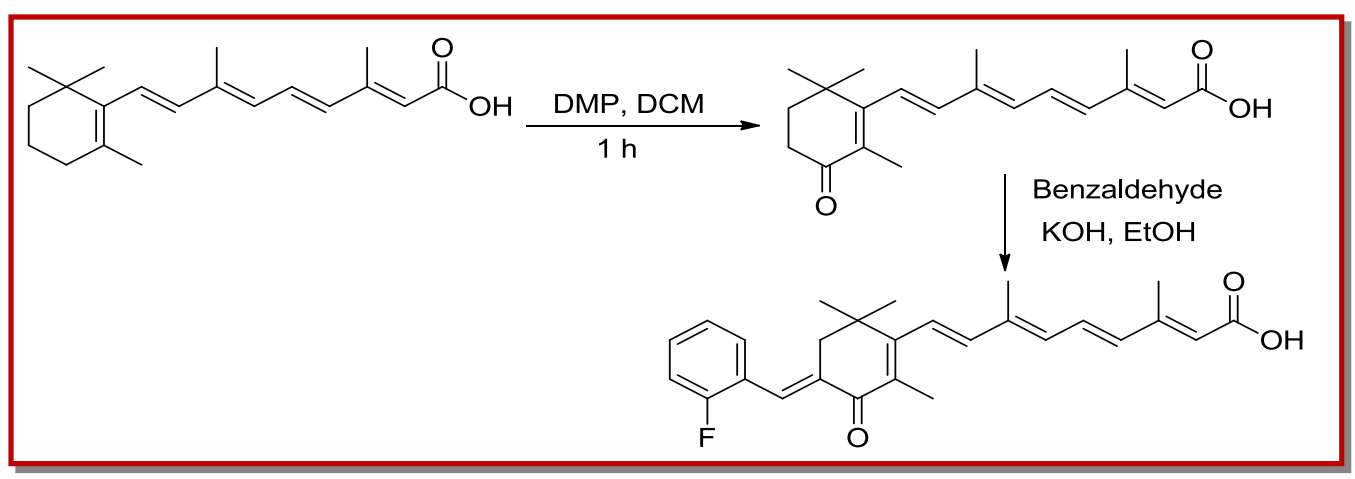

Scheme 1: Synthesis of 2-florobenzaldehyde retinoic acid chalcone 


\section{Analysis of cell cycle}

The tissue culture flasks (T-75 flask; Nunc A/S) containing RPMI-1640 medium supplemented with $2 \%$ FBS were seeded with U373 glioma cells at a density of $3 x$ $10^{6}$ cells per flask. The cells were incubated for 24 hours with various concentrations of 2-fluorobenzaldehyde retinoic acid conjugate, washed twice with ice-cold PBS buffer and fixed in 70\% ice-cold ethanol. Centrifugation of the contents from each of the flask was performed at $15000 \mathrm{xg}$ for $15 \mathrm{~min}$. The cells were washed with PBS and treated with $100 \mu \mathrm{L}$ PBS supplemented with $1 \mathrm{mM}$ RNase A (Qiagen, Hilden, Germany) for 1 hour at $37^{\circ} \mathrm{C}$. After incubation, the cells were subjected to propidium iodide $(50 \mu \mathrm{g} / \mathrm{mL}$; Sigma-Aldrich) staining for $20 \mathrm{~min}$. FACSV antage SE flow cytometry system and cell quest program (BD Biosciences) were used to analyze the DNA content after cells were filtered through a $40 \mu \mathrm{m}$ nylon mesh (BD Biosciences, USA).

\section{Statistical analysis}

All the data expressed are the mean \pm SD. One-way ANOVA was used for the analysis of the data obtained and comparisons were made using Mann-Whitney U test. $\mathrm{p}$-value $<0.05$ was considered statistically significant in all the cases.

\section{Results}

\section{Inhibition of U373 glioma cell proliferation}

The results from BrdU assay revealed that 2-fluorobenzaldehyde retinoic acid conjugate exhibited inhibitory effect on cell proliferation in U373 glioma cells in a dose and time-dependent manner. Increase in the concentration of 2-fluorobenzaldehyde retinoic acid conjugate from $10-50 \mu \mathrm{M}$, reduced the viability of U373 cells from 98 to $19 \%$ after 48 hours. The proportion of viable cells at $6,12,24,36$ and 48 hours following treatment with the compound were $96,81,76,43$ and $19 \%$, respectively (Figure 2).

\section{Inhibition of constitutive STAT3 activation}

The results from Western blot analysis revealed that 2fluorobenzaldehyde retinoic acid conjugate inhibited the activation of STAT3 in U373 cells. Inhibition of STAT3 in U373 cells was significant at $50 \mu \mathrm{M}$ concentration of RAC after 3 hours, without any effect on STAT3 protein (Figure 3). Treatment of U373 cells with AG490 (50 $\mu \mathrm{mol} / \mathrm{L})$, inhibitor of JAK2-STAT3 activation inhibited STAT3 phosphorylation similar to 2-fluorobenzaldehyde retinoic acid conjugate (Figure 3 ).

\section{Inhibition of inducible JAK2 phosphorylation}

Treatment of U373 cells with IL-6 significantly induced phosphorylation of JAK2 after 15 min. However, when U373 cells were pretreated with RAC followed by IL-6 treatment a marked reduction in the phosphorylation of JAK2 was observed after 2 hours (Figure 4).

Effect on expression of Bax and Bak proteins and antiapoptotic gene

Analysis of the effect of 2-fluorobenzaldehyde retinoic acid conjugate on the expression of Bax and Bak proteins in U373 glioma cells revealed a significant increase after 24 hours (Figure 5A). RAC treatment caused a marked reduction in the expression of cyclin D1, Bcl-2, BclxL, survivin and VEGF in U373 cells after 24 hours (Figure 5B). In addition, the expression of Mcl-1 was also inhibited by RAC after 24 hours in U373 cells (Figure 5C).

\section{Effect on cell cycle distribution}

Analysis of cell cycle distribution revealed a marked increase in the population of cells in G1 phase on RAC treatment after 24 hours. On the other hand, RAC treatment for 48 hours led to a significant increase in the population of cells in sub-G1 phase (Figure 6).

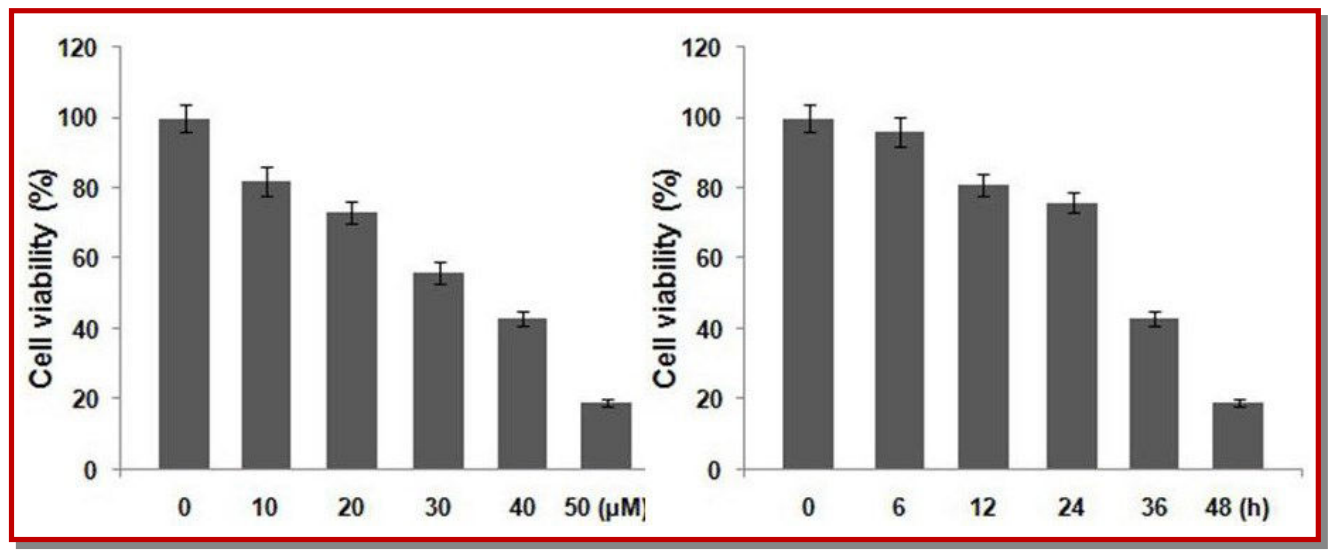

Figure 2: 2-Florobenzaldehyde retinoic acid conjugate inhibited proliferation of U373 glioma cells in a concentration- and timedependent manner. The cells after treatment with conjugate were analyzed using BrdU assay 


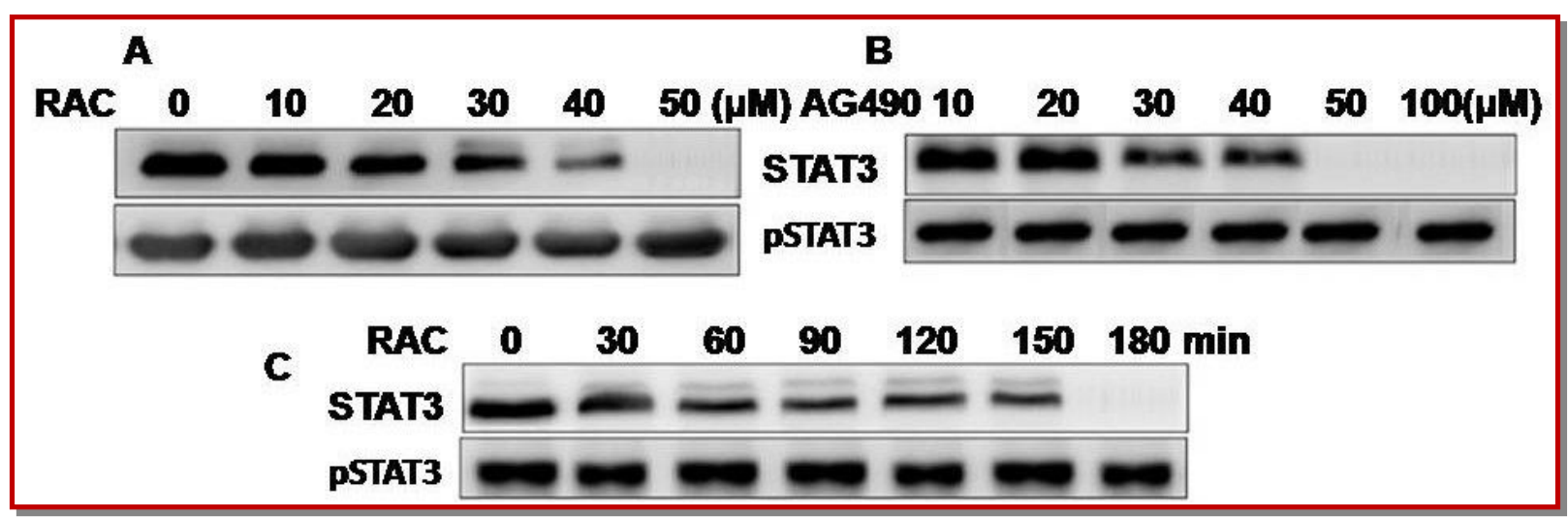

Figure 3: Effect of 2-florobenzaldehyde retinoic acid conjugate and AG490 on activation of STAT3 in U373 cells. (A) 2florobenzaldehyde retinoic acid conjugate inhibited phospho-STAT3 levels in a dose-dependent manner in U373 cells. (B) AG490 inhibited activation of STAT3 phosphorylation in U373 cells after 8 hours. (C) 2-florobenzaldehyde retinoic acid conjugate suppresses phospho-STAT3 levels in U373 cells in 3 hours

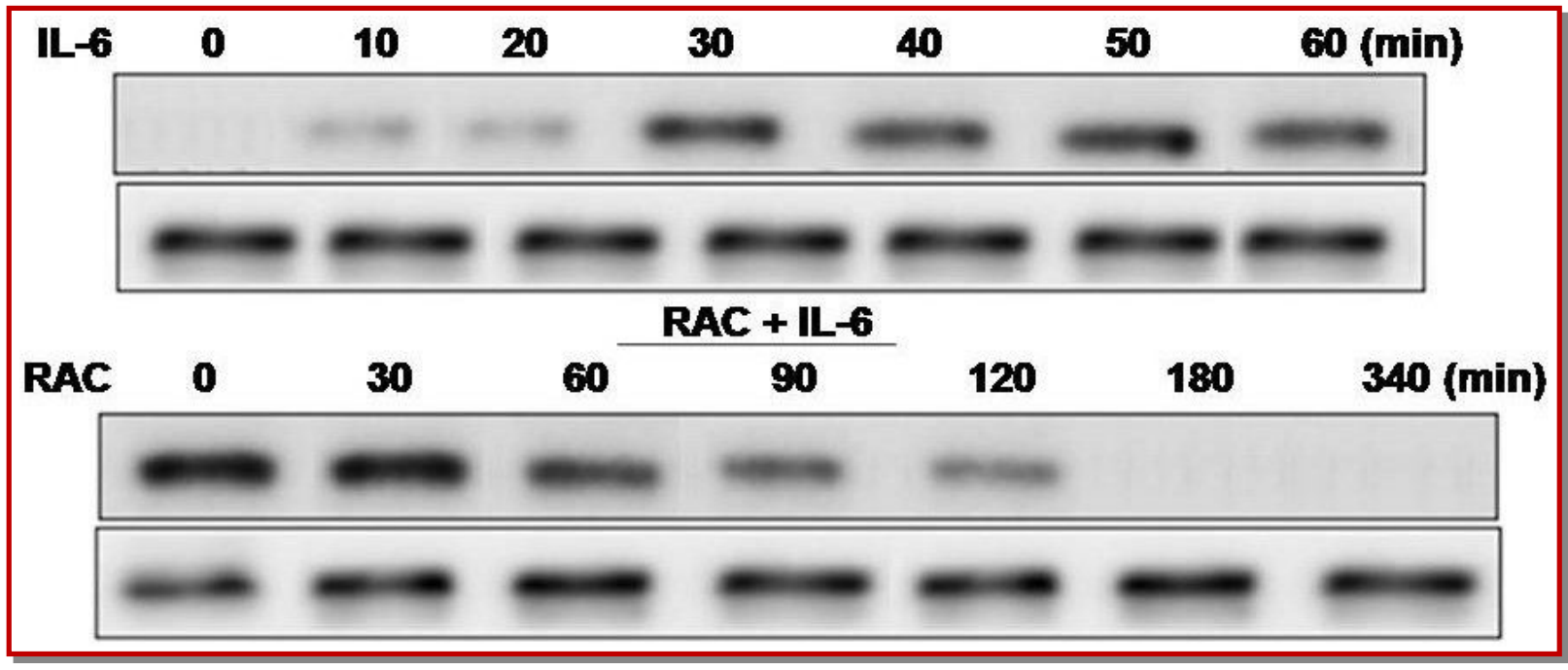

Figure 4: 2-Florobenzaldehyde retinoic acid conjugate inhibited IL-6-induced phospho-STAT3. IL-6 enhanced the expression of JAK2 protein. RAC inhibited IL-6 induced expression of JAK2 protein

\section{Discussion}

The present study was performed to investigate the anticancer effects of 2-fluorobenzaldehyde retinoic acid conjugate through inhibition of STAT3 signaling pathway in glioma cells. It was observed that RAC treatment inhibited the phosphorylation of constitutive as well as IL-6 induced STAT3. The expression of proapoptotic genes, including cyclin D1, survivin, Bcl-2, Bcl -xL, Mcl-1 and VEGF was inhibited by 2-fluorobenzaldehyde retinoic acid conjugate. Moreover, the population of glioma cells in G1-G0 phase was increased indicating the induction of apoptosis.

It is reported that AG490, a potent inhibitor of JAK2 inhibits the phosphorylation of STAT3 at a concentration of $50 \mu \mathrm{mol} / \mathrm{L}$ (Bharti et al., 2003). The results from the present study showed that RAC inhibited the activation of STAT3 at a concentration of $40 \mu \mathrm{M}$ after 3 hours in glioma cells. 2-Fluorobenzaldehyde retinoic acid conjugate treatment exhibited no influence on the expression of STAT3 protein. Phosphorylated STAT3 inhibits the induction of apoptosis in carcinoma cells and thereby promotes the process of oncogenesis (Catlett-Falcone et al., 1999). The enhanced resistance to apoptosis by activated STAT3 is believed to be mediated by the increased expression of anti-apoptotic genes, Bcl-2 and cyclin D1 (Danial et al., 1995). Our results demonstrated that 2-fluorobenzaldehyde retinoic acid conjugate inhibited the expression of cyclin D1, proliferative gene; survivin, $\mathrm{Bcl}-2, \mathrm{Bcl}-\mathrm{xL}$, and $\mathrm{Mcl}-1$, antiapoptotic gene and VEGF, angiogenic genes. The progression of cell cycle from G1 to $S$ phase in the cells is mediated by the expression of cyclin D1 (Niu et al., 1999). In the carcinoma cells $\mathrm{Bcl}-\mathrm{xL}$ is expressed in higher concentration and its expression is induced by activation of STAT3 (Niu et al., 1999). The role of Bcl-xL is to prevent the 


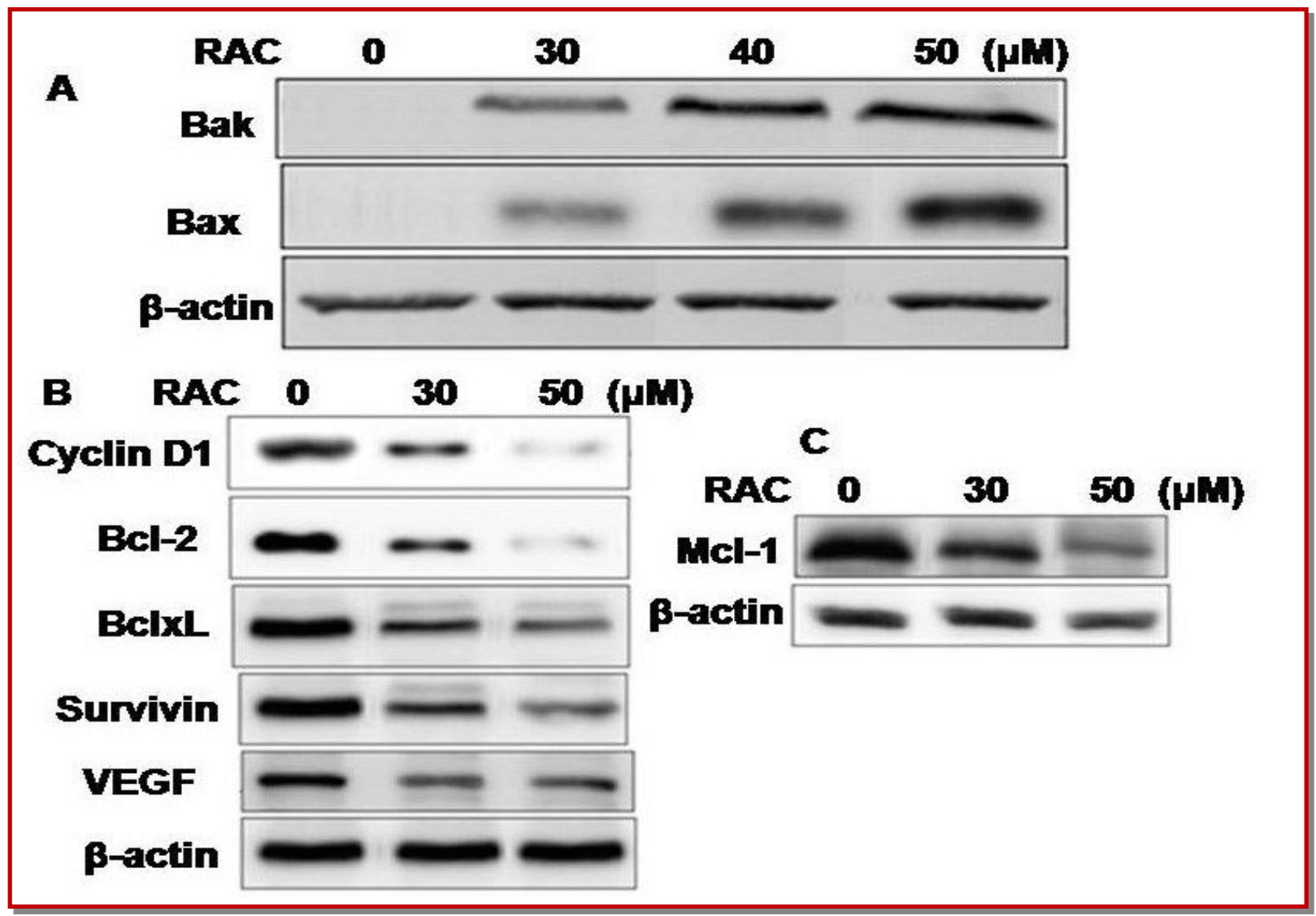

Figure 5: 2-Fluorobenzaldehyde retinoic acid conjugate promotes the expression of proapoptotic Bax and Bak proteins (A). 2Fluorobenzaldehyde retinoic acid conjugate inhibits STAT3 regulated antiapoptotic gene, cyclin D1, Bcl-2, Bcl-XL, survivin, and VEGF (B). 2-Fluorobenzaldehyde retinoic acid conjugate inhibits the expression of Mcl-1 protein (C)

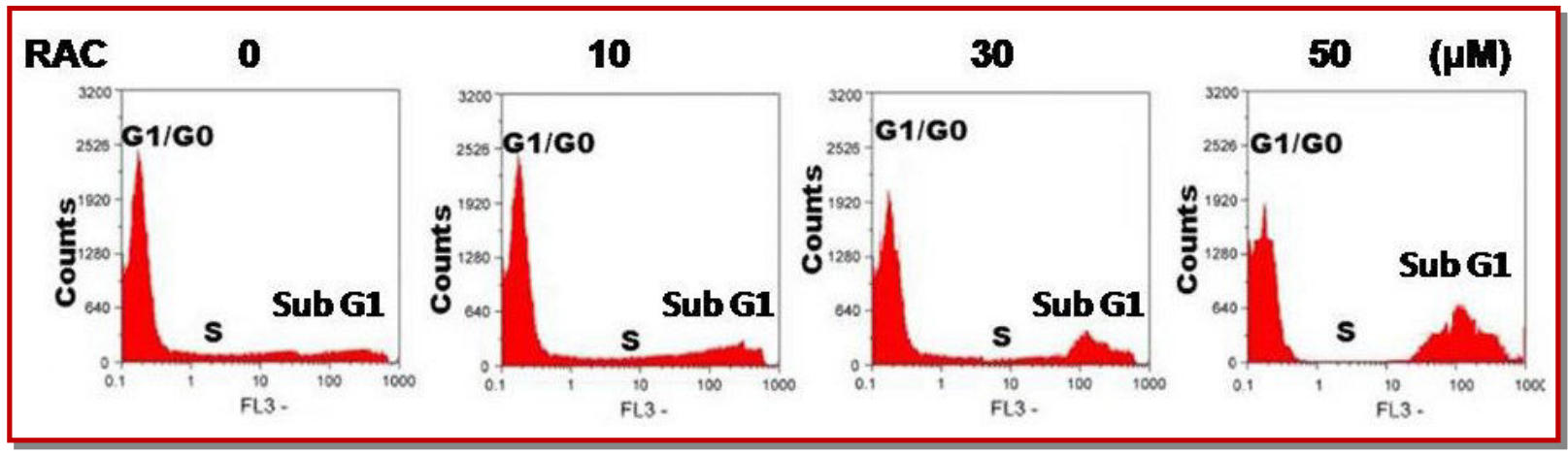

Figure 6: 2-Florobenzaldehyde retinoic increases the population of cells in G0-G1 phase in after 24 hours and in sub-G1 phase after 48 hours

process of apoptosis induced by the anti-cancer drugs (Simonian et al., 1997).

\section{Conclusion}

2-Fluorobenzaldehyde retinoic acid conjugate inhibits phosphorylation of STAT3 and JAK2, reduces the expression of cyclin D1, Bcl-2, BclxL, Mcl-1, and VEGF, inhibit cell proliferation and induce apoptosis in glioma cells.

\section{References}

Bouterfa H, Picht T, Keb D, Herbold McSC, Noll E, Black PM, Roosen K, Tonn JC. Retinoids inhibit human glioma cell proliferation and migration in primary cell cultures but not in established cell lines. Neurosurgery 2000; 46: 419-30.

Bharti AC,Donato N, Aggarwal BB. Curcumin (diferuloylmethane) inhibits constitutive and IL-6-inducible STAT3 phosphorylation in human multiple myeloma cells. J Immunol. 2003; 171: 386371. 
Buettner R, Mora LB, Jove R. Activated STAT signaling in human tumors provides novel molecular targets for therapeutic intervention. Clin Cancer Res. 2002; 8: 945-54.

Catlett-Falcone R, Landowski TH, Oshiro MM, et al., Constitutive activation of Stat3 signaling confers resistance to apoptosis in human U266 myeloma cells. Immunity 1999; 10: 105-15.

Danial NN, Pernis A, Rothman PB. Jak-STAT signaling induced by the $v$-abl oncogene. Science 1995; 269: 1875-77.

di Tomaso E, London N, Fuja D, Logie J, Tyrrell J A, Kamoun W, Munn LL, Jain RK. PDGF-C induces maturation of blood vessels in a model of glioblastoma and attenuates the response to anti-VEGF treatment. PLoS One 2009; 4: e5123.

Darnell JE, Jr. Transcription factors as targets for cancer therapy. Nat Rev Cancer 2002; 2: 740-49.

Gan HK, Lappas M, Cao DX, Cvrljevdic A, Scott AM, Johns TG. Targeting a unique EGFR epitope with monoclonal antibody 806 activates NF-kappaB and initiates tumour vascular normalization. J Cell Mol Med. 2009; 13: 3993-4001.

Gao SP, Bromberg JF. Touched and moved by STAT3. Sci STKE 2006; 2006: pe30.

Ihle JN. STATs: Signal transducers and activators of transcription. Cell 1996; 84: 331-34.

Jang FF, Wei W, De WM. Vascular endothelial growth factor and basic fibroblast growth factor expression positively correlates with angiogenesis and peritumoural brain oedema in astrocytoma. J Ayub Med Coll Abbottabad. 2008; 20: 10509.

Lin ZX, Yang LJ, Huang Q, Lin JH, Ren J, Chen ZB, Zhou LY, Zhang PF, FuJ. Inhibition of tumor-induced edema by antisense VEGF is mediated by suppressive vesiculovacuolar organelles (VVO) formation. Cancer Sci. 2008; 99: $2540-46$.

Liang JY, Fontana JA, Rao JN, Ordonez JV, Dawson MI, Shroot
B, Wilber JF, Feng P. Synthetic retinoid CD437 induces Sphase arrest and apoptosis in human prostate cancer cells LNCaP and PC-3. Prostate 1999; 38: 228-36.

Niu G, Heller R, Catlett-Falcone R, et al., Gene therapy with dominantnegative Stat3 suppresses growth of the murine melanoma B16 tumor in vivo. Cancer Res. 1999; 59: 5059-63.

Ng SS, Gao Y, Chau DH, Chau DHW , LiGHY , Lai LH, Huang PT, Huang CF, HuangJJ, Chen YC, Kung HF, Lin MCM. A novel glioblastoma cancer gene therapy using AAV-mediated long-term expression of human TERT C-terminal polypeptide. Cancer Gene Ther. 2007; 14: 561-72.

Paez-Ribes M, Allen E, Hudock J, Takeda T, Okuyama H, Viñals F, Inoue M, Bergers G, Hanahan D, Casanovas O. Antiangiogenic therapy elicits malignant progression of tumors to increased local invasion and distant metastasis. Cancer Cell. 2009; 15: 220-31.

Ren Z, Schaefer TS. ErbB-2 activates Stat3a in a Src- and JAK2dependent manner. J Biol Chem. 2002; 277: 38486-93.

Rotan R. Retinoids as modulators of tumor cell invasion and metastasis. Semin Cancer Biol. 1991; 2: 197-208

Simonian PL, Grillot DA, Nunez G. Bcl-2 and Bcl-XL can differentially block chemotherapy-induced cell death. Blood 1997; 90: 1208-16.

Yung WK, Kyritsis AP, Gleason MJ, Levin VA. Treatment of recurrent malignant gliomas with high-dose 13-cis-retinoic acid. Clin Cancer Res. 1996: 2:1931-35.

Weber E, Ravi RK, Knudsen ES, Williams JR, Dillehay LE, Nelkin BD, Kalemkerian GB, Feramisco JR, Mabry M. Retinoic acid-mediated growth inhibition of small cell lung cancer cells is associated with reduced myc and increased p27Kip1 expression. Int J Cancer. 1999; 80: 935-43.

Zheng Y, Kramer PM, Lubet RA, Steele VE, Kelloff GJ, Pereira MA. Effect of retinoids on AOM-induced colon cancer in rats: Modulation of cell proliferation, apoptosis and aberrant crypt foci. Carcinogenesis 1999; 20: 255-60. 